\title{
Absence of $\Delta$-9-Tetrahydrocannabinol Dysphoric Effects in Dynorphin-Deficient Mice
}

\author{
Andreas Zimmer, ${ }^{1,2}$ Emmanuel Valjent, ${ }^{3}$ Monika König, ${ }^{1}$ Anne M. Zimmer, ${ }^{1,2}$ Patricia Robledo, ${ }^{3}$ Heidi Hahn, ${ }^{1}$ \\ Olga Valverde, ${ }^{3}$ and Rafael Maldonado ${ }^{3}$ \\ ${ }^{1}$ Laboratory of Genetics, National Institute of Mental Health, Bethesda, Maryland 20892, ${ }^{2}$ Psychiatric Clinic, University of

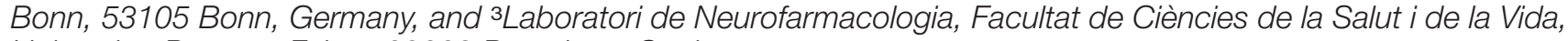 \\ Universitat Pompeu Fabra, 08003 Barcelona, Spain
}

The involvement of dynorphin on $\Delta$-9-tetrahydrocannabinol (THC) and morphine responses has been investigated by using mice with a targeted inactivation of the prodynorphin (Pdyn) gene. Dynorphin-deficient mice show specific changes in the behavioral effects of THC, including a reduction of spinal THC analgesia and the absence of THC-induced conditioned place aversion. In contrast, acute and chronic opioid effects were normal. The lack of negative motivational effects of THC in the absence of dynorphin demonstrates that this endogenous opioid peptide mediates the dysphoric effects of marijuana.

Key words: cannabinoid; opioid; mice; mutation; withdrawal; addiction; place aversion
Pharmacological and genetic evidence suggest important functional interactions between the endogenous brain cannabinoid and opioid systems (Hine et al., 1975; Vela et al., 1995; Pugh et al., 1997; Tanda et al., 1997; Ledent et al., 1999; Manzanares et al., 1999; Valverde et al., 2000, 2001). Most of the behavioral effects of endogenous cannabinoids (arachidonoyletanolamide, 2-arachidonoylglycerol, and 2-arachidonylglycerol) and $\Delta$-9-tetrahydrocannabinol (THC) are mediated by cannabinoid $\mathrm{CB}_{1}$ receptors (Ledent et al., 1999; Zimmer et al., 1999), whereas opioids (endorphin, enkephalins, and dynorphins) act on $\mu, \delta$, and $\kappa$ receptors (Kieffer, 1999). Cannabinoids and opioids produce similar behavioral and physiological effects, such as antinociception, hypothermia, and reduced locomotor activity (Manzanares et al., 1999). Both systems seem to be functionally coupled in drug reward and addiction, because opioid withdrawal symptoms were alleviated by cannabinoids (Hine et al., 1975; Lichtman et al., 2001; Yamaguchi et al., 2001) and they were significantly reduced in CB1 receptor knock-out mice (Ledent et al., 1999; Lichtman et al., 2001). CB1 receptor antagonists blocked heroin selfadministration and morphine-induced place preference (MasNieto et al., 2001; Navarro et al., 2001). Morphine-induced place preference was also abolished in $\mathrm{CB}_{1}$ receptor knock-outs (Martin et al., 2000). Conversely, THC withdrawal symptoms were significantly reduced in enkephalin-deficient animals (Valverde et al., 2000). The expression of opioid and cannabinoid receptors overlaps in many brain areas, including structures of the reward circuitry (Herkenham, 1992; Matsuda et al., 1993; Delfs et al., 1994; Mansour et al., 1995a,b). Although colocalization studies with cellular resolution have not been performed yet, it has been

Received July 17, 2001; revised Sept. 11, 2001; accepted Sept. 19, 2001.

This work was supported by European Commission BIOMED-2 Grant 98-2227 (R.M.), Fondo de Investigaciones Sanitaria Grant 99/0624 (R.M.), Dr. Esteve S. A. Laboratories (R.M.), Deutsche Forschungsgemeinschaft (Sonderforschungsbereich 400), and the Land Nordrhein-Westfalen (Innovationsprogramm Forschung) (A.Z.).

Correspondence should be addressed to Andreas Zimmer, Laboratory of Molecular Neurobiology, Clinic of Psychiatry, University of Bonn, Sigmund-Freud-Strasse 25,53125 Bonn, Germany. E-mail: neuro@uni-bonn.de.

H. Hahn's present address: Institute of Human Genetics, University of Göttingen, Heinrich-Dücker-Weg 12, 37073 Göttingen, Germany.

Copyright (C) 2001 Society for Neuroscience $0270-6474 / 01 / 219499-07 \$ 15.00 / 0$ suggested that both receptor types may interact at the level of signal transduction (Manzanares et al., 1999).

Of particular interest is the potential role of cannabis as a gateway drug, which has been investigated primarily with epidemiological methods (Watson et al., 2000). Although most recreational users of cannabis experience a state of euphoria (high), some people also report dysphoria and anxiety after cannabis use (Gregg et al., 1976; Thomas, 1993; Grinspoon and Bakalar, 1997; Williamson and Evans, 2000). Both aspects can be revealed in rodents in which conditioned place aversion or place preference can be induced through different experimental protocols (Sanudo-Pena et al., 1997; Cheer et al., 2000; Valjent and Maldonado, 2000). Compounds that activate the $\mu$ - or $\delta$-opioid receptors generally have positive motivational effects, whereas $\kappa$-opioid receptor agonists induce aversive effects (Shippenberg et al., 1987; Bals-Kubik et al., 1993). These opposing pharmacological responses may reflect an opposite modulation of the reward circuits by the different opioid receptors and could suggest that activation of $\kappa$ receptors would counteract opioid rewarding effects. Opioids and cannabinoids both produce their motivational effects through the stimulation of the mesolimbic dopaminergic system (Koob, 1992; Manzanares et al., 1999). The neuronal mechanisms for the aversive effects of THC have not been ascertained yet. The elucidation of these mechanisms is crucial for a better understanding of the processes involved in the initiation of cannabinoid abuse. THC, but not the endogenous cannabinoid anandamide, stimulates the release of the endogenous $\kappa$ agonist dynorphin, which may contribute to the antinociceptive effects of THC (Welch and Eads, 1999; Houser et al., 2000). To determine whether dynorphin is also involved in the regulation of motivational effects of THC and morphine, we investigated whether the genetic deletion of dynorphin influences several acute and chronic responses of these two drugs.

\section{MATERIALS AND METHODS}

Mice. A gene targeting vector was constructed in a pPNT-M1-lox vector using a $7 \mathrm{~kb} S m a \mathrm{I}-X b a \mathrm{I}$ fragment from a prodynophin genomic BAC clone (Research Genetics) containing exons 1 and 2 and a PCR-amplified $1.2 \mathrm{~kb}$ fragment from a genomic 129/SV lambda GEM 11 clone contain- 
ing the $3^{\prime}$ end of exon 4. This targeting construct was electroporated into MPIII embryonic stem (ES) cells (a gift from A. Voss and P. Gruss, Max-Planck-Institute for Biophysical Chemistry, Göttingen, Germany). Five ES cell clones with the expected homologous recombination event were isolated and injected into $\mathrm{C} 57 \mathrm{BL} / 6 \mathrm{~J}$ mouse blastocysts. The resulting chimeras were bred to $\mathrm{C} 57 \mathrm{BL} / 6 \mathrm{~J}$ mice. Heterozygous offspring were intercrossed to obtain homozygous mutants. Mice used in behavioral studies were between 10 and 16 weeks old. Animals were housed in groups of four to five animals per cage. The light cycle was 8:00 A.M. lights on and 8:00 P.M. lights off. Food and water was provided ad libitum. Both sexes were equally represented. All animal procedures met the guidelines of the National Institutes of Health detailed in the Guide for the Care and Use of Laboratory Animals and the European Communities directive 86/609/EEC regulating animal research and were approved by the Local Ethical Committees.

Radioimmunoassay. Mouse brains (five for each genotype) were homogenized in $3 \mathrm{ml}$ of $2 \mathrm{~N}$ acetic acid at $4^{\circ} \mathrm{C}$ and clarified at $15,000 \times g$ for $30 \mathrm{~min}$ at $4^{\circ} \mathrm{C}$. Duplicate aliquots of 10,50 , and $100 \mu \mathrm{l}$ were dried under vacuum in polystyrene tubes (Falcon 35 2052), resuspended in $100 \mu \mathrm{l}$ of RIA (Peninsula Laboratories, San Carlos, CA) buffer, and assayed following the protocol for the RIK 8730 Dynorphin A (Porcine) Radioimmunoassay kit from Peninsula Laboratories. The range for the standard curve for this kit was between 0.1 and $64 \mathrm{pg}$.

Drugs. Morphine- $\mathrm{HCl}$, naloxone- $\mathrm{HCl}, \mathrm{U} 50,488 \mathrm{H}$, nor-binaltorphimine (NBI), and THC were provided by Sigma (St. Louis, MO). THC was diluted to a working solution in $10 \%$ ethanol-10\% cremophor EL-80\% distilled water. Morphine, naloxone, NBI, and U50,488H were dissolved in $0.9 \%$ saline. SR141716A was generously provided by Sanofi Recherche (Libourne, France) and was dissolved in 10\% ethanol-10\% cremophor EL-80\% distilled water. The volume of injection was $1 \mathrm{ml} / 100 \mathrm{gm}$ for morphine, naloxone, U50,488H, NBI, and THC and $1 \mathrm{ml} / 50 \mathrm{gm}$ for SR141716A.

Nociceptive tests. Basal nociceptive thresholds were measured using the tail-immersion and the hot-plate tests. In the tail-immersion test, mice were maintained in a cylinder, and their tail was immersed in water at 48 , 50 , and $52^{\circ} \mathrm{C}$. Latency to tail withdrawal was measured with a cutoff period of $15 \mathrm{sec}$ to avoid tissue damage. In the hot-plate test, the mice were placed on a hot surface heated at $52^{\circ} \mathrm{C}$, and the latency for paw licking and jumping was recorded. The cutoff periods for licking and jumping were 30 and $240 \mathrm{sec}$, respectively.

Acute drug effects. Locomotor activity responses induced by acute administration of morphine $(5 \mathrm{mg} / \mathrm{kg}$, s.c. $)$, the $\kappa$-opioid receptor agonist U50,488H (7.5 mg/kg, s.c.), and THC (20 mg/kg, i.p.) were evaluated using locomotor activity cages $(9 \times 20 \times 11 \mathrm{~cm}$; Imetronic, Passac, France). The boxes were equipped with one line of photocells placed 2 $\mathrm{cm}$ above the floor to measure horizontal movements and another line 6 $\mathrm{cm}$ above the floor to measure vertical activity (rears). Mice were habituated to the locomotor cages twice daily (15 min in the morning and $15 \mathrm{~min}$ in the afternoon) on 2 consecutive days. On the third day, mice were placed in the locomotor cages $15 \mathrm{~min}$ after drug injection, and ambulatory activity and total locomotor activity (ambulatory movements plus small movements) were recorded for $10 \mathrm{~min}$ in a low luminosity environment (20-25 lux). Antinociceptive responses to acute treatment with morphine ( 2 and $5 \mathrm{mg} / \mathrm{kg}$, s.c.), U50,488H $(7.5 \mathrm{mg} / \mathrm{kg}$, s.c.), and THC (20 mg/kg, i.p.) were measured 2 min after drug injection in both the tail-immersion (water temperature at $50^{\circ} \mathrm{C}$ ) and the hot-plate tests. The effects of THC $(20 \mathrm{mg} / \mathrm{kg}$, i.p.) on rectal temperature were measured 20 min after drug injection by using an electronic thermocouple flexible probe (Panlab, Barcelona, Spain). The probe was placed $3 \mathrm{~cm}$ into the rectum of the mice for $30 \mathrm{sec}$ before the temperature was recorded. Control mice were treated with vehicle under the same conditions in all of the experiments.

THC tolerance and withdrawal. Mice were injected intraperitoneally twice daily at 9:00 A.M. and 7:00 P.M. during $5 \mathrm{~d}$ with THC (20 mg/kg) or vehicle. On day 6 , mice only received the morning injection. Three different responses were measured during the chronic THC treatment: body weight, rectal temperature, and antinociception. Body weights were recorded for each animal twice per day using an electronic balance [Mettler PM 4800 (sensitive to $0.01 \mathrm{gm}$ ); Mettler Toledo Inc., Columbus, $\mathrm{OH}]$, before all morning and evening injections. The changes in body weight were calculated by subtracting each weight value from the precedent value. Effects of THC on rectal temperature were measured on days 1 and 2 , immediately before and $20 \mathrm{~min}$ after each injection. On days 3 , 4,5 , and 6 , rectal temperature was evaluated before and $20 \mathrm{~min}$ after the morning injection only. Antinociceptive responses were measured using the tail-immersion assay $\left(50^{\circ} \mathrm{C}\right)$, just after rectal temperature measurement, $20 \mathrm{~min}$ after morning (everyday) and evening (days 1 and 2) injections. On the sixth day, $4 \mathrm{hr}$ after the last THC or vehicle injections, mice were placed in a circular clear plastic observation area $(30 \mathrm{~cm}$ diameter, $80 \mathrm{~cm}$ height) for a $15 \mathrm{~min}$ period of observation. SR141716A (10 $\mathrm{mg} / \mathrm{kg}$, i.p.) was administered, and mice were then replaced in the same area and observed for $45 \mathrm{~min}$. Measurement of somatic signs before and after SR141716A challenge were divided in 5 min time intervals, as described previously (Hutcheson et al., 1998). The number of bouts of sniffing, writhing, wet-dog shake, and forepaw tremor were counted. Penile licking or erection, ataxia, hunched posture, tremor, ptosis, and piloerection were scored 1 for appearance and 0 for nonappearance within each $5 \mathrm{~min}$ time period. Scores for the level of activity were made by giving in each 5 min period a value: 0 , low activity; 1 , normal activity; or 2 , increased activity. A quantitative value was calculated in each animal for the different checked signs by adding the scores obtained in each 5 min time period. A global withdrawal score, ranging from 0 to 100 , was calculated for each animal by giving to each individual sign a relative weight, as described previously (Valverde et al., 2000): 0.9 point for the appearance of each checked sign in each $5 \mathrm{~min}$ time period and 0.4 point for each bout of counted sign.

Morphine withdrawal. Opiate dependence was induced by repeated intraperitoneal injections of morphine at an interval of $12 \mathrm{hr}$ over $6 \mathrm{~d}$ (Valverde et al., 2000). The morphine dose was increased progressively as follows: first day, $20 \mathrm{mg} / \mathrm{kg}$; second day, $40 \mathrm{mg} / \mathrm{kg}$; third day, $60 \mathrm{mg} / \mathrm{kg}$; fourth day, $80 \mathrm{mg} / \mathrm{kg}$; fifth day, and $100 \mathrm{mg} / \mathrm{kg}$; sixth day (only one injection in the morning), $100 \mathrm{mg} / \mathrm{kg}$. Control mice were treated with saline under the same conditions. Withdrawal was precipitated by injecting naloxone $(1 \mathrm{mg} / \mathrm{kg}$, s.c.) $2 \mathrm{hr}$ after the last morphine administration and was evaluated during $30 \mathrm{~min}$ as reported previously (Maldonado et al., 1996). The number of bouts of jumping, wet-dog shakes, forepaw tremor, and sniffing were counted. Body tremor, ptosis, diarrhea, teeth chattering, and piloerection were scored 1 for appearance or 0 for nonappearance within each 5 min time. A global withdrawal score was calculated for each animal by using a range of possible scores from 0 to 100, as described previously (Koob et al., 1992).

Place conditioning paradigm. An unbiased place conditioning procedure was used to evaluate the aversive properties of THC (Valjent and Maldonado, 2000) and the rewarding effects of morphine (Maldonado et al., 1997). The apparatus consisted of two main squared conditioning compartments $(15 \times 15 \times 15 \mathrm{~cm})$ separated by a triangular central division. The light intensity within the conditioning chambers was $20 \pm$ 5 lux. The movement and location of the mice were monitored by computerized monitoring software (Videotrack; View Point, Lyon, France) with images relayed from a camera placed above the apparatus. During the preconditioning phase, drug naive mice were placed in the middle of the central division and had free access to both compartments of the conditioning apparatus for $20 \mathrm{~min}$, with the time spent in each compartment being recorded. For morphine experiments, the conditioning phase consisted of three pairings with morphine $(5 \mathrm{mg} / \mathrm{kg}$, s.c. $)$ and three pairings with saline for a $30 \mathrm{~min}$ conditioning time (Maldonado et al., 1997). For THC experiments, the conditioning phase consisted of five pairings with THC ( $5 \mathrm{mg} / \mathrm{kg}$, i.p.) and five pairings with vehicle for a 45 min period (Valjent and Maldonado, 2000). Mice were injected with vehicle or drug and then immediately confined to the conditioning compartment. The drug-assigned compartment could be either the most or the least preferred. Treatments were counterbalanced as closely as possible between compartments. Control animals received vehicle every day. The test phase was conducted exactly as the preconditioning phase, i.e., free access to each compartment for $20 \mathrm{~min}$. The time in the central area was proportionally shared and added to the time value of each conditioned compartment, as described previously (Maldonado et al., 1997). A place conditioning score was calculated for each animal as the difference between time spent in the drug-paired compartment during the test and preconditioning phases. Experiments with NBI (Sigma) were performed in $\mathrm{CD}_{1}$ mice $(22-24 \mathrm{gm})$. Ninety minutes after pretreatment with NBI $(0,5$, and $10 \mathrm{mg} / \mathrm{kg}$, s.c. $)$, mice were injected intraperitoneally with vehicle or THC $(5 \mathrm{mg} / \mathrm{kg}$, i.p.) and placed in the conditioning compartment. Six groups of mice were formed: saline-vehicle, 5 $\mathrm{mg} / \mathrm{kg}$ NBI-vehicle, $10 \mathrm{mg} / \mathrm{kg}$ NBI-vehicle, saline-THC, $5 \mathrm{mg} / \mathrm{kg} \mathrm{NBI}-$ $\mathrm{THC}$, and $10 \mathrm{mg} / \mathrm{kg} \mathrm{NBI-THC}$.

Statistical analysis. At least 10 animals were used for each behavioral test. Acute effects and global withdrawal scores were compared by using two-way ANOVA (genotype and treatment) between subjects, followed by one-way ANOVA for individual differences. Values of tolerance 

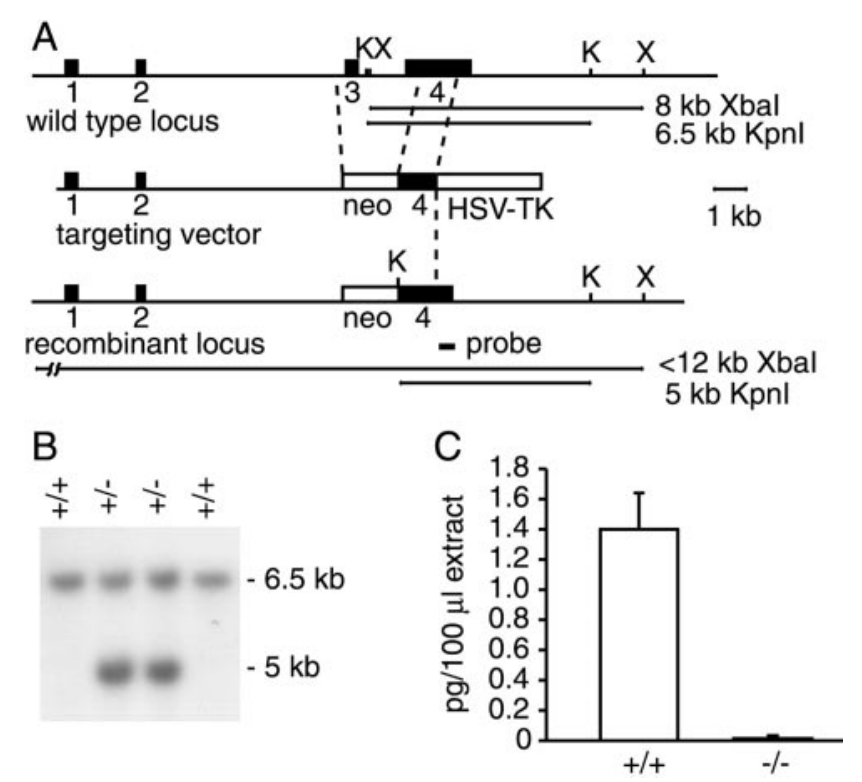

Figure 1. Generation of Pdyn ${ }^{-1-}$ mice. A, Map of the wild-type Pdyn locus, the targeting construct, and the $P d y n^{-1-}$ locus. The $3^{\prime}$ external probe used for Southern blot analysis and the expected restriction fragments are indicated. $K, K p n \mathrm{I} ; X, X b a \mathrm{I}$. B, Genotyping of offspring from $P d y n^{+/+} \times P d y n^{+/-}$crosses by Southern blot analysis of mouse tail DNA. $C$, Analysis of dynorphin peptide levels from whole brain extracts of $P d y n^{+1+}$ and $P d y n^{-1-}$ mice. Shown are the average values (means \pm SEM) from five animals per genotype.

studies were compared by using three-way ANOVA (genotype and treatment as between-group factors and day as within-group factor), followed by corresponding two-way and one-way ANOVA and post hoc comparisons when required. For place conditioning studies, score values were compared by using two-way ANOVA between subjects (genotype and treatment), followed by one-way ANOVA. Time spent in the drug-paired compartment during pretest in the different groups was compared by a one-way ANOVA to ensure use of an unbiased procedure. Individual comparisons of time spent in the drug-paired compartment during preconditioning and test phases were made with paired two-tailed Student's $t$ test.

\section{RESULTS}

We inactivated the prodynorphin gene (Pdyn) by deleting exon 3 and part of exon 4 (Fig. $1 A, B$ ). This genetic mutation deletes the translation initiation codon of the dynorphin gene to generate a null allele. Analysis of whole brain extracts by radioimmunoassays showed that, indeed, mice homozygous for the $P d y n^{\text {tm1zim }}$ mutation (henceforth referred to as $P d y n^{-1-}$ ) did not produce any dynorphin peptides (Fig. $1 C$ ). $P d y n^{-1-}$ mice were obtained with the expected Mendelian frequency. They did not show any apparent developmental defects, were fertile, and raised their offspring.

Locomotor activity of dynorphin-deficient mice was evaluated in an open-field system. Horizontal and vertical movements were similar in $P d y n^{+/+}$and $P d y n^{-1-}$ mice, indicating that dynorphin is not essential for normal motor functions. As has been reported previously (Wang et al., 2001), we also did not find any differences between wild-type and dynorphin knock-out mice in tests for thermal pain sensitivity.

First, we evaluated the responses of dynorphin-deficient mice to opioids. Injection of the $\kappa$ agonist U50,488H $(7.5 \mathrm{mg} / \mathrm{kg}$, i.p.) reduced locomotor activity in both genotypes (Fig. $2 A$ ), whereas morphine $(5 \mathrm{mg} / \mathrm{kg}$, s.c.) induced a similar increase in horizontal locomotion in $P d y n^{+/+}$and $P d y n^{-/-}$mice (Fig. $2 B$ ) compared

\section{A $\quad U 50,488 \mathrm{H}$}

Tail Immersion

Locomotion

Rearings
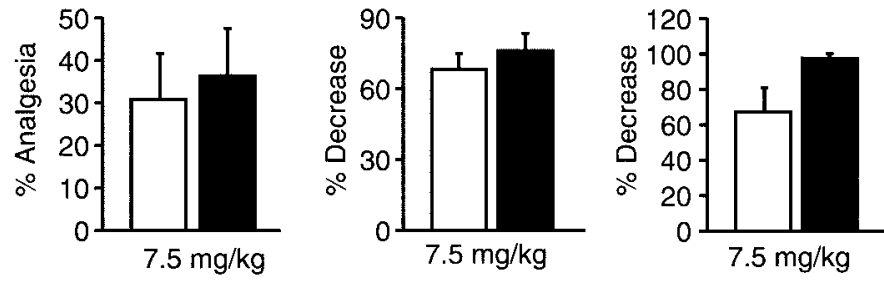

B Morphine
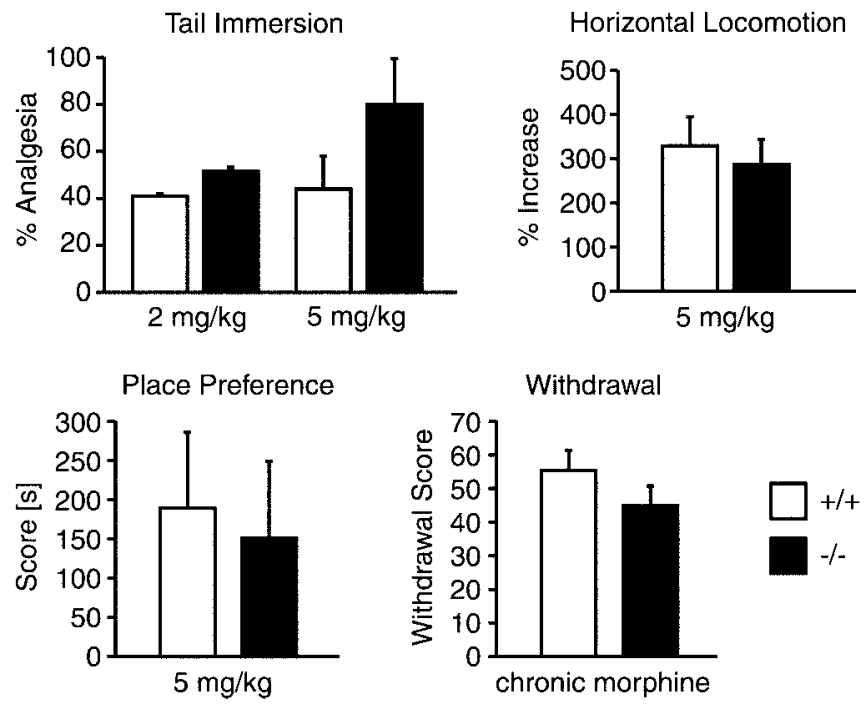

Figure 2. Effects of U50,488H and morphine. A, Acute antinociceptive effects of the $\kappa$-selective ligand $\mathrm{U} 50,488 \mathrm{H}$ and vehicle were determined on the tail-immersion test. Maximum percentage of analgesia was calculated as [(postinjection latency - baseline latency)/(cutoff time - baseline latency) $] \times 100$. Locomotor effects were evaluated in activity boxes, by measuring horizontal and vertical beam breaks (rears). No significant differences were observed in these tests between $P d y n^{+/+}$and $P d y n^{-1-}$ mice. $B$, Morphine antinociception, also evaluated by determining tailimmersion analgesia, was not significantly different in $P d y n^{+/+}$and $P d y n^{-1-}$ mice at intraperitoneal doses of 2 and $5 \mathrm{mg} / \mathrm{kg}$. We also found no differences in morphine-induced hyperactivity or in the conditioned place preference test. Morphine withdrawal symptoms, elicited in chronically treated mice through naloxone administration, were also unchanged by the lack of dynorphin. All values are expressed as means \pm SEM.

with saline injection. Thus, locomotor effects of opioids also appeared to be unchanged in $P d y n^{-1-}$ mice. Injection of U50,488H (7.5 mg/kg, i.p.) also produced similar analgesia in $\mathrm{Pdyn}^{+/+}$and $\mathrm{Pdyn}{ }^{-/-}$mice in the tail-immersion test (Fig. 2A). In addition, no significant differences between genotypes were observed in this nociceptive assay after intraperitoneal administration of morphine at the dose of 2 and $5 \mathrm{mg} / \mathrm{kg}$ (Fig. 2B). These data indicate that acute antinociceptive responses to opioid ligands are not substantially altered in dynorphin-deficient mice.

The involvement of endogenous dynorphin in the rewarding properties of morphine $(5 \mathrm{mg} / \mathrm{kg})$ was studied by using the conditioned place preference paradigm (Fig. $2 B$ ). $P d y n^{+/+}$and $P d y n^{-1-}$ mice displayed a similar conditioned place preference, indicating that the neuronal mechanisms that mediate the rewarding effects of morphine are not influenced by the dynorphin deficiency. In contrast to $\kappa$ receptor knock-out mice, $P d y n^{-1-}$ and 


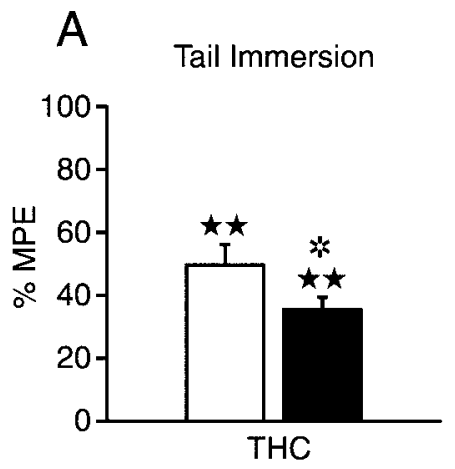

B

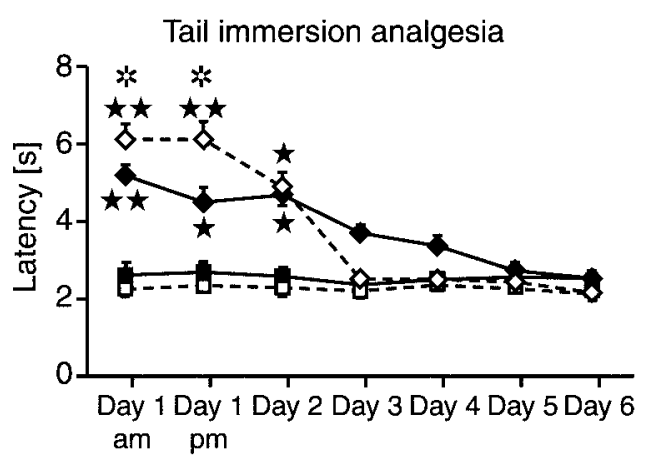

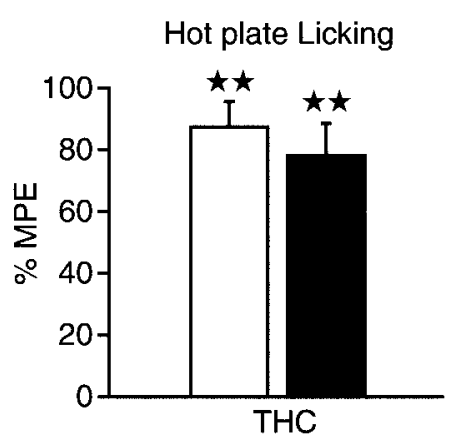
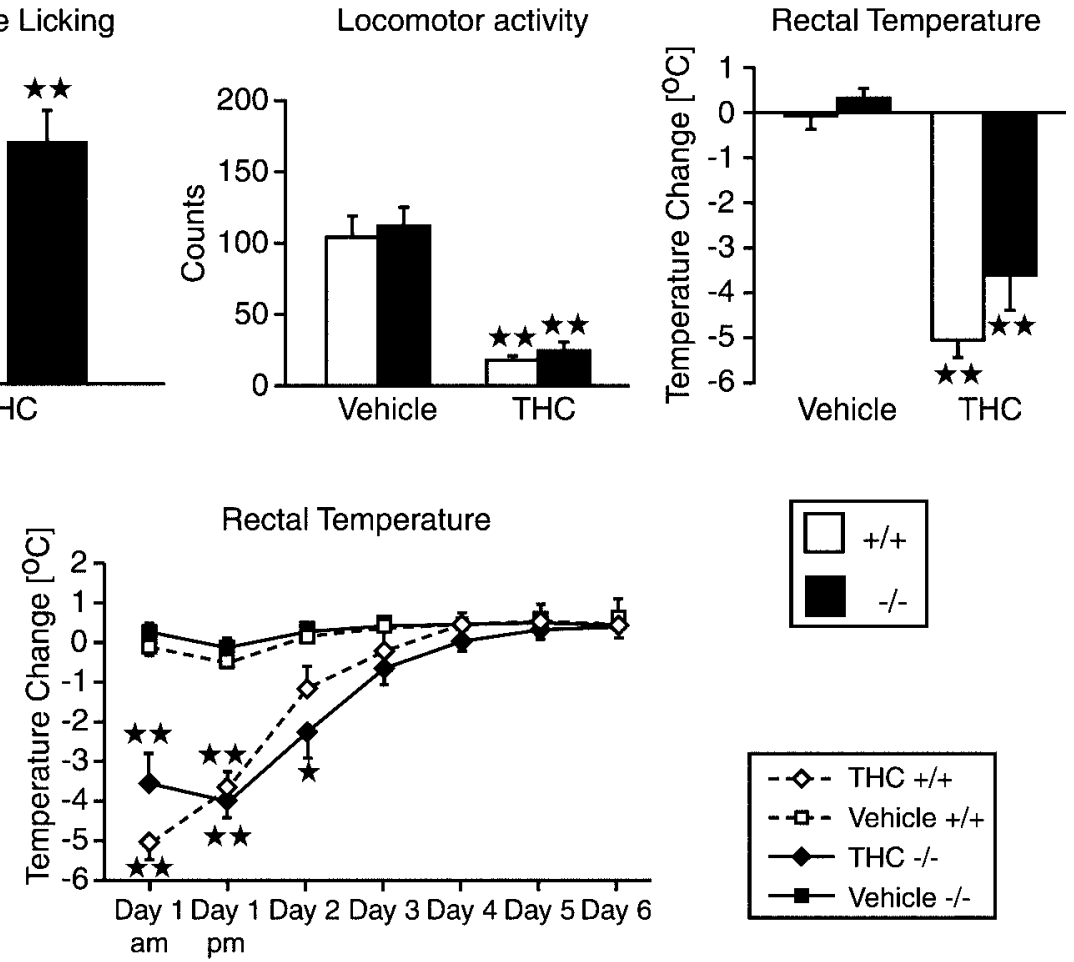

Figure 3. THC acute responses and tolerance. A, Acute antinociceptive effects of vehicle and THC (20 mg/kg, i.p.) were determined in Pdyn ${ }^{+/+}$and $P d y n^{-1-}$ mice on the tail-immersion and hot-plate tests. THC effects on locomotor activity were determined in activity boxes and THC hypothermia using a rectal probe. All values are expressed as means \pm SEM. $B$, Development of tolerance to the effects of chronic THC ( $20 \mathrm{mg} / \mathrm{kg}$, i.p., twice daily) were evaluated by measuring tail-immersion analgesia and changes in body temperature. ${ }^{*} p<0.05$, comparison between genotypes; $\star p<0.05$ and $\star \star p<$ 0.01, comparison with vehicle-treated animals of the same genotype (one-way ANOVA).

$P d y n^{+/+}$mice also showed no significant differences in morphine abstinence symptoms (Fig. $2 B$ ), suggesting that dynorphin does not participate in the development and expression of morphine dependence.

Next, we evaluated the effects of the dynorphin deletion on acute responses induced by THC ( $20 \mathrm{mg} / \mathrm{kg}$, i.p.). THC analgesia was similar in both genotypes in the hot-plate test, but the tail-immersion test revealed a significantly reduced analgesia in $P d y n^{-1-}$ animals $(p<0.05)$ (Fig. $\left.3 A\right)$. In contrast to THC analgesia, THC-induced hypoactivity and reduction in body temperature were not affected by the dynorphin mutation (Fig. 3A).

Recurrent administration of THC reduced its antinociceptive and hypothermic effects (Hutcheson et al., 1998). Both Pdyn ${ }^{-1-}$ and $P d y n^{+/+}$mice developed a similar degree of tolerance over a period of $6 \mathrm{~d}$ of testing (Fig. $3 B$ ). Somatic signs of withdrawal can be observed in chronically THC-treated animals after administration of the cannabinoid receptor antagonist SR141716A. These symptoms included wet-dog shakes, hunched posture, ptosis, tremor, piloerection, and mastication. Like opioid withdrawal, these behaviors are thought to be caused by adaptive neuronal changes that are revealed by antagonist-induced cessation of receptor activation (Hutcheson et al., 1998). When we injected SR141716A (10 mg/kg) at the end of the chronic THC treatment, we observed a tendency for reduced expression of somatic withdrawal symptoms in $P d y n^{-1-}$ animals (global withdrawal score: $\left.P d y n^{+/+}, 68.5 \pm 5.2 ; P d y n^{-/-}, 52.0 \pm 4.2\right)$ that did not, however, reach significance $(p=0.059)$. On the whole, our results indicate that the dynorphin deficiency does not substantially influence adaptive neuronal changes after chronic THC treatment.
We next explored the motivational effects of THC in $P d y n^{-/-}$ mice in a place conditioning paradigm. THC has dysphoric properties in mice under most experimental conditions and produces a conditioned place aversion (Manzanares et al., 1999). Accordingly, $P d y n^{+/+}$mice conditioned with a dose of $5 \mathrm{mg} / \mathrm{kg}$ THC spent significantly $(p<0.01)$ less time in the drug-paired compartment and obtained a lower place conditioning score $(p<$ 0.01) (Fig. 4). In contrast, dynorphin-deficient mice injected with THC spent the same amount of time in the drug-paired as in the saline-paired compartment and showed a neutral place conditioning score. Thus, THC-induced conditioned place aversion was completely suppressed in $P d y n^{-1-}$ mice.

To further investigate the role of the dynorphin- $-\kappa$-opioid receptor system in the expression of THC place aversion, mice were treated with the $\kappa$-specific antagonist NBI before the administration of THC in the place preference paradigm. As shown in Figure 5, NBI treatment also completely eliminated the development of THC-induced conditioned place aversion $(p<0.05)$.

\section{DISCUSSION}

In this study, we generated mice with a targeted deletion of the prodynorphin gene and analyzed the effects of this mutation on opioid and cannabinoid drug responses. The antinociceptive effects of the $\kappa$-selective ligand U50,488H were unaltered. In addition, morphine antinociception, reward, and naloxone-precipitated morphine withdrawal were also unaffected by the dynorphin mutation. These findings were unexpected because the recent analysis of $\kappa$ receptor knock-outs (Simonin et al., 1998) suggested an involvement of the $\kappa$-opioid system in the modulation of morphine depen- 
A

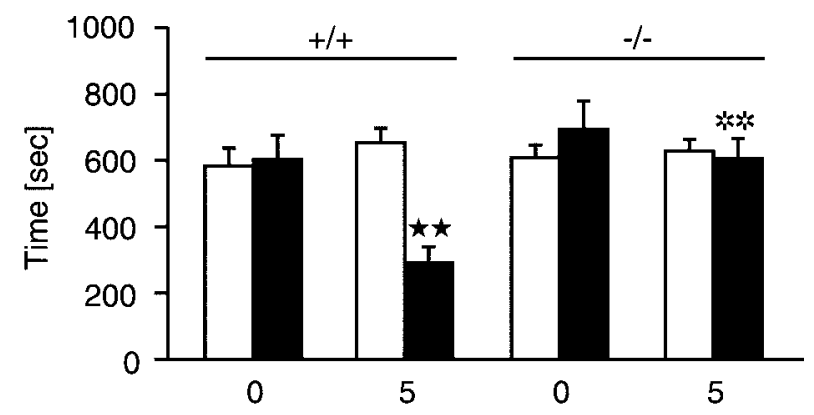

B

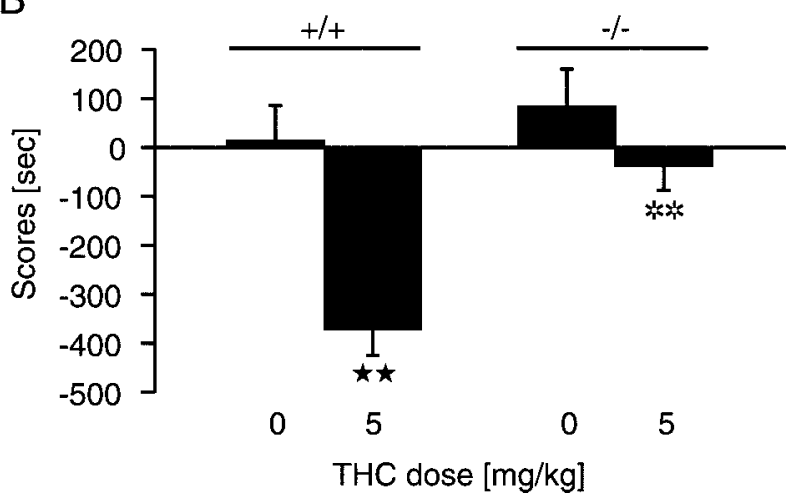

Figure 4. Lack of THC-induced place aversion in dynorphin-deficient mice. Place conditioning was induced by vehicle and THC ( $5 \mathrm{mg} / \mathrm{kg}$, i.p) administration. $A$, Time spent in the drug-paired compartment during preconditioning (white columns) and testing (black columns) phases. $B$, Scores calculated as the difference between test and preconditioning time spent in the drug-paired compartment. All values are expressed as means \pm SEM. $* * p<0.01$, comparison between genotypes; $\star \star p<0.01$, comparison between treatments (one-way ANOVA).

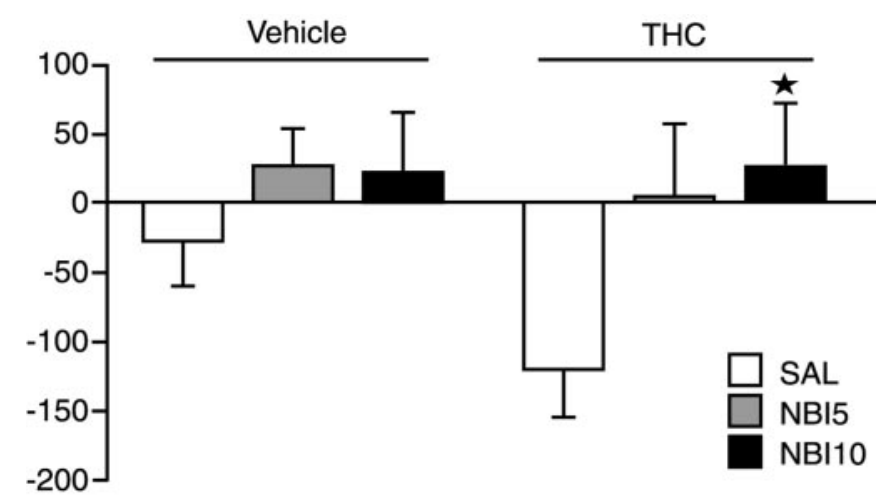

Figure 5. Lack of THC-induced place aversion in mice pretreated with NBI. Animals were injected with 0, 5 (NBI5), or 10 (NBI10) $\mathrm{mg} / \mathrm{kg}$ NBI 90 min before the injection with saline $(S A L)$ or THC. $\star p<0.01$, comparison between treatments (one-way ANOVA)

dence, because mice lacking the $\kappa$ receptor displayed an attenuation of naloxone-precipitated morphine withdrawal. The decreased morphine abstinence in $\kappa$-deficient mice could be attributable to a direct activation of $\kappa$-opioid receptors, considering the high doses of morphine used in this study (Simonin et al., 1998) and the lack of selectivity of this compound. Altogether, our results show that most pharmacological effects of opioids are unchanged in dynorphin-deficient mice.

In contrast, THC analgesia, as determined in the tail-immer- sion test, was significantly reduced in $P d y n^{-1-}$ mice. This result strongly supports a role of dynorphin, or other opioid peptides generated by the Pdyn gene, in THC analgesia. It is concordant with findings that have implicated the activation of $\mu$-opioid and, preferentially, $\kappa$-opioid receptors in the antinociceptive mechanism of THC (Welch, 1993; Reche et al., 1996; Pugh et al., 1997; Welch and Eads, 1999). However, previous pharmacological studies of opioid-cannabinoid interactions in nociception were ambiguous. Although the $\kappa$ receptor-selective antagonist norbinaltorphimine or dynorphin antisera could block the antinociceptive effects of intrathecally administered THC (Welch, 1993; Reche et al., 1996; Pugh et al., 1997; Mason et al., 1999), other studies using opioid antagonists did not support an involvement of opioid receptors in cannabinoid analgesia (Martin, 1985; Calignano et al., 1998; Meng et al., 1998). However, other mechanisms different from $\kappa$-opioid receptors could be also involved in the decrease of THC antinociception in $P d y n^{-1-}$ mice. Indeed, pharmacological studies indicate that dynorphin may act not only at the $\kappa$ receptor but also on other receptors, including $\mu$ - and $\delta$-opioid receptors (Zhang et al., 1998) and the NMDA receptor (Bakshi and Faden, 1990; Dumont and Lemaire, 1994; Shukla et al., 1997).

Most strikingly, dynorphin-deficient mice do not show any manifestation of THC-conditioned place avoidance. Furthermore, pretreatment of mice with NBI also completely abolished the development of THC place aversion in wild-type animals. Together, these results strongly indicate that the dynorphin $-\kappa$ opioid receptor system is crucial for the manifestation of cannabinoid aversive effects. A mechanism for the interaction between opioid and cannabinoid systems in motivational drug effects could involve the increased synthesis and release of opioid peptides in brain regions that regulate drug reward after THC treatment. This hypothesis is supported by studies demonstrating the release of dynorphin after THC administration at the level of the spinal cord (Mason et al., 1999; Houser et al., 2000) and the induction of opioid peptide gene expression in the spinal cord (Corchero et al., 1997b), hypothalamus (Kumar and Chen, 1983; Corchero et al., 1997a, 1999), and periaqueductal gray (Manzanares et al., 1998). However, recent studies have shown that the aversive effects of the $\kappa$ agonist $\mathrm{U} 50,488 \mathrm{H}$ are also blunted in cannabinoid $\mathrm{CB}_{1}$ receptor knock-out mice (Ledent et al., 1999), which indicates that dynorphin is not a simple downstream regulator of the aversive effects of THC. It rather appears that the cannabinoidand dynorphin- $\kappa$-opioid systems act in concert in the modulation of negative motivational drug effects.

Our findings do not exclude the possibility that other systems, such as the corticotropin releasing factor (CRF), are involved in the modulation of THC dysphoric effects as well. CRF has been implicated in THC and stress responses (Weidenfeld et al., 1994; Rodriguez de Fonseca et al., 1996, 1997). CB $_{1}$ receptors are expressed in CRF-containing neurons in the hypothalamus and limbic structures, including the medial prefrontal cortex, hippocampus, and amygdala (Herkenham et al., 1991). Long-term cannabinoid administration alters CRF function in the limbic system (Rodriguez de Fonseca et al., 1997).

The selectivity of the observed THC-motivational effects cannot be defined in the present study. Indeed, stimulation of $\kappa$-opioid receptors through endogenous dynorphins in response to other dysphoric-aversive stimuli has been reported (Staley et al., 1997; Hutchinson et al., 2000). Additional studies will be performed to determine whether the motivational responses of other aversive stimulus are also modified in prodynorphin knockout mice. 
In summary, our results demonstrate for the first time that the endogenous opioid peptides generated from the dynorphin gene are crucial for the negative motivational effects of THC and participate in the spinal analgesia induced by this compound. This is in agreement with the idea that the activation of cannabinoid receptors stimulates the production and release of endogenous opioid peptides. The disappearance of the dysphoric effects of THC after repeated exposure to the drug (Valjent and Maldonado, 2000) could be essential for the initiation of cannabinoid abuse. The present results clearly indicate that endogenous dynorphin controls this important cannabinoid motivational response.

\section{REFERENCES}

Bakshi R, Faden AI (1990) Competitive and non-competitive NMDA antagonists limit dynorphin A-induced rat hindlimb paralysis. Brain Res 507:1-5.

Bals-Kubik R, Ableitner A, Herz A, Shippenberg TS (1993) Neuroanatomical sites mediating the motivational effects of opioids as mapped by the conditioned place preference paradigm in rats. J Pharmacol Exp Ther 264:489-495.

Calignano A, La Rana G, Giuffrida A, Piomelli D (1998) Control of pain initiation by endogenous cannabinoids. Nature 394:277-281.

Cheer JF, Kendall DA, Marsden CA (2000) Cannabinoid receptors and reward in the rat: a conditioned place preference study. Psychopharmacology 151:25-30.

Corchero J, Fuentes JA, Manzanares J (1997a) delta 9-Tetrahydrocannabinol increases proopiomelanocortin gene expression in the arcuate nucleus of the rat hypothalamus. Eur J Pharmacol 323:193-195.

Corchero J, Avila MA, Fuentes JA, Manzanares J (1997b) delta-9Tetrahydrocannabinol increases prodynorphin and proenkephalin gene expression in the spinal cord of the rat. Life Sci 61:39-43.

Corchero J, Manzanares J, Fuentes JA (1999) Repeated administration of delta9-tetrahydrocannabinol produces a differential time related responsiveness on proenkephalin, proopiomelanocortin and corticotropin releasing factor gene expression in the hypothalamus and pituitary gland of the rat. Neuropharmacology 38:433-439.

Delfs JM, Kong H, Mestek A, Chen Y, Yu L, Reisine T, Chesselet MF (1994) Expression of mu opioid receptor mRNA in rat brain: an in situ hybridization study at the single cell level. J Comp Neurol 345:46-68.

Dumont M, Lemaire S (1994) Dynorphin potentiation of [ $\left.{ }^{3} \mathrm{H}\right] \mathrm{CGP}-$ 39653 binding to rat brain membranes. Eur J Pharmacol 271:241-244.

Gregg JM, Small EW, Moore R, Raft D, Toomey TC (1976) Emotional response to intravenous delta-9-tetrahydrocannabinol during oral surgery. J Oral Surg 34:301-313.

Grinspoon L, Bakalar JB (1997) Marihuana, the forbidden medicine, pp 234-252. New Haven, CT: Yale UP.

Herkenham M (1992) Cannabinoid receptor localization in brain: relationship to motor and reward systems. Ann NY Acad Sci 654:19-32.

Herkenham M, Lynn AB, Johnson MR, Melvin LS, de Costa BR, Rice KC (1991) Characterization and localization of cannabinoid receptors in rat brain: a quantitative in vitro autoradiographic study. J Neurosci 11:563-583.

Hine B, Friedman E, Torrelio M, Gershon S (1975) Morphinedependent rats: blockade of precipitated abstinence by tetrahydrocannabinol. Science 187:443-445.

Houser SJ, Eads M, Embrey JP, Welch SP (2000) Dynorphin B and spinal analgesia: induction of antinociception by the cannabinoids CP55,940, Delta(9)-THC and anandamide. Brain Res 857:337-342.

Hutcheson DM, Tzavara ET, Smadja C, Valjent E, Roques BP, Hanoune J, Maldonado R (1998) Behavioural and biochemical evidence for signs of abstinence in mice chronically treated with delta-9tetrahydrocannabinol. Br J Pharmacol 125:1567-1577.

Hutchinson AC, Simpson GR, Randall JF, Zhang X, Calderon SN, Rice KC, Riley AL (2000) Assessment of SNC 80 and naltrindole within a conditioned taste aversion design. Pharmacol Biochem Behav 66:779-787.

Kieffer BL (1999) Opioids: first lessons from knockout mice. Trends Pharmacol Sci 20:19-26.

Koob GF (1992) Drugs of abuse: anatomy, pharmacology and function of reward pathways. Trends Pharmacol Sci 13:177-184.

Koob GF, Maldonado R, Stinus L (1992) Neural substrates of opiate withdrawal. Trends Neurosci 15:186-191.

Kumar MS, Chen CL (1983) Effect of an acute dose of delta 9-THC on hypothalamic luteinizing hormone releasing hormone and metenkephalin content and serum levels of testosterone and corticosterone in rats. Subst Alcohol Actions Misuse 4:37-43.

Ledent C, Valverde O, Cossu G, Petitet F, Aubert JF, Beslot F, Bohme GA, Imperato A, Pedrazzini T, Roques BP, Vassart G, Fratta W, Parmentier M (1999) Unresponsiveness to cannabinoids and reduced addictive effects of opiates in CB1 receptor knockout mice. Science 283:401-404.

Lichtman AH, Sheikh SM, Loh HH, Martin BR (2001) Opioid and cannabinoid modulation of precipitated withdrawal in delta(9)tetrahydrocannabinol and morphine-dependent mice. J Pharmacol Exp Ther 298:1007-1014.

Maldonado R, Blendy JA, Tzavara E, Gass P, Roques BP, Hanoune J, Schutz G (1996) Reduction of morphine abstinence in mice with a mutation in the gene encoding CREB. Science 273:657-659.

Maldonado R, Saiardi A, Valverde O, Samad TA, Roques BP, Borrelli E (1997) Absence of opiate rewarding effects in mice lacking dopamine D2 receptors. Nature 388:586-589.

Mansour A, Fox CA, Akil H, Watson SJ (1995a) Opioid-receptor mRNA expression in the rat CNS: anatomical and functional implications. Trends Neurosci 18:22-29.

Mansour A, Fox CA, Burke S, Akil H, Watson SJ (1995b) Immunohistochemical localization of the cloned mu opioid receptor in the rat CNS. J Chem Neuroanat 8:283-305.

Manzanares J, Corchero J, Romero J, Fernandez-Ruiz JJ, Ramos JA, Fuentes JA (1998) Chronic administration of cannabinoids regulates proenkephalin mRNA levels in selected regions of the rat brain. Brain Res Mol Brain Res 55:126-132.

Manzanares J, Corchero J, Romero J, Fernandez-Ruiz JJ, Ramos JA, Fuentes JA (1999) Pharmacological and biochemical interactions between opioids and cannabinoids. Trends Pharmacol Sci 20:287-294.

Martin BR (1985) Structural requirements for cannabinoid-induced antinociceptive activity in mice. Life Sci 36:1523-1530.

Martin M, Ledent C, Parmentier M, Maldonado R, Valverde O (2000) Cocaine, but not morphine, induces conditioned place preference and sensitization to locomotor responses in CB1 knockout mice. Eur J Neurosci 12:4038-4046.

Mas-Nieto M, Pommier B, Tzavara ET, Caneparo A, Da Nascimento S, Le Fur G, Roques BP, Noble F (2001) Reduction of opioid dependence by the CB(1) antagonist SR141716A in mice: evaluation of the interest in pharmacotherapy of opioid addiction. $\mathrm{Br} \mathrm{J}$ Pharmacol 132:1809-1816.

Mason Jr DJ, Lowe J, Welch SP (1999) Cannabinoid modulation of dynorphin A: correlation to cannabinoid-induced antinociception. Eur J Pharmacol 378:237-248.

Matsuda LA, Bonner TI, Lolait SJ (1993) Localization of cannabinoid receptor mRNA in rat brain. J Comp Neurol 327:535-550.

Meng ID, Manning BH, Martin WJ, Fields HL (1998) An analgesia circuit activated by cannabinoids. Nature 395:381-383.

Navarro M, Carrera MR, Fratta W, Valverde O, Cossu G, Fattore L Chowen JA, Gomez R, del Arco I, Villanua MA, Maldonado R, Koob GF, de Fonseca FR (2001) Functional interaction between opioid and cannabinoid receptors in drug self-administration. J Neurosci 21:5344-5350.

Pugh Jr G, Mason Jr DJ, Combs V, Welch SP (1997) Involvement of dynorphin B in the antinociceptive effects of the cannabinoid CP55,940 in the spinal cord. J Pharmacol Exp Ther 281:730-737.

Reche I, Fuentes JA, Ruiz-Gayo M (1996) A role for central cannabinoid and opioid systems in peripheral delta 9-tetrahydrocannabinolinduced analgesia in mice. Eur J Pharmacol [Erratum (1996) 312:391] 301:75-81.

Rodriguez de Fonseca F, Rubio P, Menzaghi F, Merlo-Pich E, Rivier J, Koob GF, Navarro M (1996) Corticotropin-releasing factor (CRF) antagonist [D-Phe12,Nle21,38,C alpha MeLeu37]CRF attenuates the acute actions of the highly potent cannabinoid receptor agonist HU-210 on defensive-withdrawal behavior in rats. J Pharmacol Exp Ther 276:56-64.

Rodriguez de Fonseca F, Carrera MRA, Navarro M, Koob GF, Weiss F (1997) Activation of corticotropin-releasing factor in the limbic system during cannabinoid withdrawal. Science 276:2050-2054.

Sanudo-Pena MC, Tsou K, Delay ER, Hohman AG, Force M, Walker JM (1997) Endogenous cannabinoids as an aversive or counter-rewarding system in the rat. Neurosci Lett 223:125-128.

Shippenberg TS, Bals-Kubic R, Herz A (1987) Motivational properties of opioids: evidence that an activation of $\delta$-receptors mediates reinforcement processes. Brain Res 436:234-239.

Shukla VK, Prasad JA, Lemaire S (1997) Nonopioid motor effects of dynorphin A and related peptides: structure dependence and role of the $N$-methyl-D-aspartate receptor. J Pharmacol Exp Ther 283:604-610.

Simonin F, Valverde O, Smadja C, Slowe S, Kitchen I, Dierich A, Le Meur M, Roques BP, Maldonado R, Kieffer BL (1998) Disruption of the kappa-opioid receptor gene in mice enhances sensitivity to chemical visceral pain, impairs pharmacological actions of the selective kappa-agonist U-50,488H and attenuates morphine withdrawal. EMBO J 17:886-897.

Staley JK, Rothman RB, Rice KC, Partilla J, Mash DC (1997) к2 opioid receptors in limbic areas of the human brain are upregulated by cocaine in fatal overdose victims. J Neurosci 17:8225-8233.

Tanda G, Pontieri FE, Di Chiara G (1997) Cannabinoid and heroin activation of mesolimbic dopamine transmission by a common mu1 opioid receptor mechanism. Science 276:2048-2050. 
Thomas H (1993) Psychiatric symptoms in cannabis users. Br J Psychiatry 163:141-149.

Valjent E, Maldonado R (2000) A behavioural model to reveal place preference to delta 9-tetrahydrocannabinol in mice. Psychopharmacology 147:436-438.

Valverde O, Maldonado R, Valjent E, Zimmer AM, Zimmer A (2000) Cannabinoid withdrawal syndrome is reduced in pre-proenkephalin knock-out mice. J Neurosci 20:9284-9289.

Valverde O, Noble F, Beslot F, Dauge V, Fournie-Zaluski MC, Roques BP (2001) Delta9-tetrahydrocannabinol releases and facilitates the effects of endogenous enkephalins: reduction in morphine withdrawal syndrome without change in rewarding effect. Eur J Neurosci 13:1816-1824.

Vela G, Ruiz-Gayo M, Fuentes JA (1995) Anandamide decreases naloxone-precipitated withdrawal signs in mice chronically treated with morphine. Neuropharmacology 34:665-668.

Wang Z, Gardell LR, Ossipov MH, Vanderah TW, Brennan MB, Hochgeschwender U, Hruby VJ, Malan Jr TP, Lai J, Porreca F (2001) Pronociceptive actions of dynorphin maintain chronic neuropathic pain. J Neurosci 21:1779-1786.

Watson SJ, Benson Jr JA, Joy JE (2000) Marijuana and medicine: assessing the science base: a summary of the 1999 Institute of Medicine report. Arch Gen Psychiatry 57:547-552.
Weidenfeld J, Feldman S, Mechoulam R (1994) Effect of the brain constituent anandamide, a cannabinoid receptor agonist, on the hypothalamopituitary-adrenal axis in the rat. Neuroendocrinology 59:110-112.

Welch SP (1993) Blockade of cannabinoid-induced antinociception by norbinaltorphimine, but not $N, N$-diallyl-tyrosine-Aib-phenylalanineleucine, ICI 174,864 or naloxone in mice. J Pharmacol Exp Ther 265:633-640.

Welch SP, Eads M (1999) Synergistic interactions of endogenous opioids and cannabinoid systems. Brain Res 848:183-190.

Williamson EM, Evans FJ (2000) Cannabinoids in clinical practice Drugs 60:1303-1314.

Yamaguchi T, Hagiwara Y, Tanaka H, Sugiura T, Waku K, Shoyama Y, Watanabe S, Yamamoto T (2001) Endogenous cannabinoid, 2-arachidonoylglycerol, attenuates naloxone-precipitated withdrawal signs in morphine-dependent mice. Brain Res 909:121-126.

Zhang S, Tong Y, Tian M, Dehaven RN, Cortesburgos L, Mansson E, Simonin F, Kieffer B, Yu L (1998) Dynorphin A as a potential endogenous ligand for four members of the opioid receptor gene family. J Pharmacol Exp Ther 286:136-141.

Zimmer A, Zimmer AM, Hohmann AG, Herkenham M, Bonner TI (1999) Increased mortality, hypoactivity, and hypoalgesia in cannabinoid CB1 receptor knockout mice. Proc Natl Acad Sci USA 96:57805785 . 